Colonies, but is otherwise arranged on similar lines. There is no further information indicating the proportion which scientific and technical persons now bear to the Service as a whole, but in issuing the pamphlet the Colonial Office Information Department states that outstanding vacancies are now less than a thousand-the lowest level since the end of the War-and that about 1,290 men and women were selected for higher posts in the Service during the first nine months of 1950 ; this figure compares with 1,414 in the whole of $1949,1,163$ in 1948 and 1,169 in 1947. Some sixty per cent of the vacancies are for posts in Africa. The medical service, which requires some two hundred candidates, and the engineering and education services, which each require a hundred and fifty, are the branches with greatest need for candidates, and medical practitioners are needed most in Malaya and East and West Africa. The information regarding opportunities offered and conditions of service is again supple. mented by a list of sources of information for certain appointments not within the Colonial Service and an excellent list of recommended books about the Service and the Colonies.

\section{Physical Society's Annual Exhibition}

IN connexion with the Physical Society's forthcoming annual Exhibition of Instruments and Apparatus, to be held during April 6-11 (excluding Sunday) at the Imperial College of Science and Technology, Exhibition Road, London, S.W.7 (see Nature, January 13, p. 61), the following discourses will be delivered: April 6 at 6.15 p.m., "Electric Currents in the Sea", by Dr. G. R. Deacon ; April 9 at 6.15 p.m., "The Age of Newton", by Dr. D. McKie; April 10 at 6.15 p.m., "The Friction of Metals, Non-Metals and the Influence of Surface Films", by Dr. F. P. Bowden ; April 11 at 3.45 p.m., "The Light Division of the National Physical Laboratory", by Dr. L. A. Sayce. Further details of the Exhibition can be obtained from the Physical Society, 1 Lowther Gardens, Prince Consort Road, London, S.W.7.

\section{Exhibitions in Paris of Scientific Instruments}

THE forty-eighth annual Exhibition of Scientific Instruments and Apparatus organized by the French Physical Society will be held, as in previous years, in Paris at the Sorbonne, during May 11-12 and 15-17 at the following times: $2.30-6.30$ p.m. and 8.30 11 p.m. On the same days and at the same times, an exhibition of British scientific research instruments will be held independently at the Sorbonne, in which university and government laboratories as well as private British industrial firms will participate. The address of the committee in charge of the French Exhibition is 12 rue Cuvier, Paris, 5 e.

\section{University of Birmingham}

Dr. W. E. BURCham, at present lecturer in physics in the Cavendish Laboratory, Cambridge, has been appointed professor of physics in the University of Birmingham. Dr. A. J. Francis has resigned his lectureship in civil engineering in the University on appointment as professor of civil engineering in the University of Melbourne. The following have recently been appointed lecturers at Birmingham: D. F. Bracher (physics), H. V. Hill (civil engineering) and W. M. Gorman (statistics). The degree of D.Sc. has been conferred on I. A. Preece for work on industrial fermentation.

\section{Announcements}

H.R.H. THE DUKe of EdinkURGH has been elected an Honorary Fellow of the Royal Society of Edinburgh.

Dr. A. M. BallantYNe, senior lecturer in the Civil and Municipal Engineering Department of University College, London, has been appointed to succeed Captain J. Laurence Pritchard as secretary of the Royal Aeronautical Society. Dr. Ballantyne will take over his duties on July 2.

Ramsay Memorial Fellowships are being offered for chemical research, one of which is limited to candidates educated in Glasgow. Their value is $£ 400$ a year, with a grant for research expenses not exceeding $£ 100$ a year, and they are normally tenable for two years. Application forms (to be completed by April 17) can be obtained from the secretaries of the Ramsay Memorial Fellowships Trust, University College, London, Gower Street, W.C.1.

The Medical Research Council is offering a number of fellowships for medical graduates with a year of clinical experience to make further studies preparatory to undertaking clinical research. The fellowships are for the academic year, beginning in October, and are renewable for a further two years. Their value is

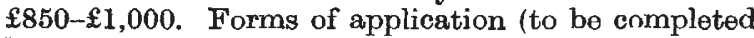
by April 30) can be obtained from the secretary of the Medical Research Council, 38 Old Queen Street, London, S.W.1.

THe Ministry of Agriculture and Fisheries is offering the following scholarships for rural workers, or the children of rural workers, of seventeen years of age or more: ten senior scholarships, tenable at universities or colleges, for degree or diploma courses in an agricultural subject or veterinary science; sixty junior scholarships (and six extensions for existing holders), tenable at farm institutes or similar institutions, for one-year courses in agriculture, horticulture, dairying or poultry husbandry. Selection is by interview only. Further information and application forms (to be completed by March 31) can be obtained from the Secretary (Room 314), 1 Cambridge Terrace, Regent's Park, London, N.W.1, or from the education offices of County Councils.

The National Physical Laboratory, Teddington, is holding its 'Open Days' for industrial representatives during May 28-29 from 10.30 a.m. to 5.30 p.m. These 'Open Days', held this year in conjunction with the Festival of Britain, are an opportunity for scientific and technical workers in industry to see the research work and special investigations undertaken at the Laboratory. Tickets are available for accredited representatives of industrial organizations, and can be obtained by writing to the Director, National Physical Laboratory, Teddington, Middlesex, not later than May 8, indicating the day of choice.

A JUNIOR study course of lectures for beginners in information and special library work, similar to that held in previous years, has been organized by Aslib and will be given at Chaucer House, Malet Place, London, W.C.1, during April 9-14. In addition to the five formal lectures, visits to places of interest and discussion groups will be arranged. The fee for the course is 2 guineas (single day, 14s.) with a nonmember surcharge of $10 \mathrm{~s}$. Further details can be obtained from Aslib, 4 Palace Gate, London, W.8. 